\title{
Music in the Life Skills classroom
}

\author{
E u r i k a Jansen van Vuuren ${ }^{1^{*}}$ and $\mathrm{C}$ a r o l i n e van Ni e $\mathrm{k}$ e $r \mathrm{k}^{2}$ \\ ${ }^{1}$ University of Johannesburg, Johannesburg, South Africa \\ ${ }^{2}$ University of Pretoria, Pretoria, South Africa \\ *eurikajvv@uj.ac.za, caroline@mweb.co.za
}

\section{Keywords}

Creative Arts, curriculum, generalist educators, in-service training, Life Skills, mentoring, music, preservice training.

\begin{abstract}
Generalist educators in South Africa shy away from music in the subjects Life Skills (Dance, Drama, Music, Visual Art, Physical Education and Personal and Social Well-being) and Creative Arts (Dance, Drama, Music, Visual Art) and universities are not delivering generalist students for the subject demands. In-service educators as well as subject advisors have often had no music training. The twofold purpose of the study reported on in this article was to determine the extent of challenges experienced in the music component of Life Skills and Creative Arts in South Africa and how this can best be dealt with.
\end{abstract}

Mixed methods research was conducted to ascertain the problems experienced with music tuition in Life Skills and Creative Arts classrooms. It was found that generalist educators have to teach music, whether they have the requisite skills or not. The subject has low status and is frequently used as a filler subject for teachers. Lack of music knowledge, scarce resources, limited support and everchanging educators are some reasons for the absence of quality music tuition. Mentoring by competent subject advisors and senior educators and the re-alignment of school and university curricula will assist music in enjoying its rightful place in the school curriculum. 


\section{Introduction}

The current study addresses real life challenges in South Africa where music is taught as part of the subject Life Skills (Grade R-6) and Creative Arts (Grade 7-9). This article focuses on the music component, although there is a knowledge vacuum amongst educators regarding the teaching of most of the four art forms (dance, drama, music, visual art) in the curriculum. Educators are not offering the required content and often use the allocated lessons to complete work from other subjects. This situation is brought about by a variety of factors. Intervention at different levels is of importance to ensure the quality and future existence of music in classrooms.

Van der Merwe (2009), lecturer at the North West University (NWU), addressed the challenges brought about by the curriculum in her article, 'Evaluating conceptual progression of music assessment standards in the learning Area Arts and Culture.' Although the curriculum has undergone a number of positive changes since her article and Arts and Culture is now part of the subject Life Skills, many of the findings remain relevant. This article supports Van der Merwe's research and expands on it by focusing on educator challenges rather than curriculum challenges. It is argued that insufficient preservice educator training and in-service educator upgrading, contributes to the overall dilemma in the subject.

The core research problem investigated was:

What is the nature and extent of the challenges experienced in the music component of Life Skills and Creative Arts (LS/CA) in South African schools? What are possible solutions that will address these challenges?

The study aimed to:

- determine the extent of pre-service educator training in the subjects LS/CA in South African universities

- ascertain the qualifications and circumstances of in-service educators in LS/CA and

- $\quad$ suggest possible solutions to remedy the current situation where music is not thriving and is showing bad results. 
Yearbooks of universities and school curricula were scoured for information about the content of generalist educator programs and matched to the aspects that need to be covered in the LS/CA in school curricula. LS/CA educators in the Vryheid district of the Zululand region of Northern KwaZulu Natal (NKZN), one of the most economically challenged rural areas in the country, were interviewed and requested to complete questionnaires. Other respondents included LS/CA subject advisors (education specialists) from other South African provinces.

The first part of this article contains a literature and human resources review which is followed by a section on methodology. Results and findings are given in a subsequent section, followed by a discussion and possible solutions.

\section{Literature/Human resources review}

Human resources were the main information source since little research has been done in these fairly new subjects (LS/CA) in South Africa. The most relevant material was found within schools and from individual educators and subject advisors.

\section{Specific aims and advantages of the subjects Life Skills (LS) and Creative Arts (AC)}

To understand the challenges of LS/CA, it is necessary to know the aims of the subject as stated in the South African National Curriculum and Policy Statement (CAPS 2011:9 ). 'It aims to expose learners to a range of knowledge, skills and values that strengthen their creative and aesthetic side through engaging in dance, music, drama and visual art activities.'

The White Paper on the Reconstruction and Development Program (1994:9) highlights the advantages of Creative Arts. It states:

Creative Arts are a critical component of developing our human resources. This will help in unlocking the creativity of our people, allowing for cultural diversity within the process of developing a unifying national culture, rediscovering our historical heritage, and assuring that adequate resources are allocated. 
Although this White Paper does not necessarily refer to the school subjects that contain Arts and Culture but rather to the wider concept, it is still very relevant since the foundation for the arts is largely created within schools. When the arts are healthy, positive community changes come about as mentioned by The Arts Education Partnership (AEP) (Stevenson \& Deasy, 2005) who started research in 2001 aimed at answering the following question: 'How do the arts contribute to the improvement of schools that serve economically disadvantaged communities?' The research showed that learners and educators alike, who are actively involved in the arts, have moved from passivity to activity and have changed from being receivers to being creators. The AEP research is of great value to South Africa where a large part of the community can be classified as economically disadvantaged when considering that the country has a 25.2\% unemployment rate (South Africa, 2013). According to the AEP research, schools with a high poverty rate that often battle poor public images and low expectations for success were turned around with active arts involvement.

\section{Pre-service educator training}

Specific training for LS/CA as encompassed in the school curriculum is rare in South African

generalist educators' training courses. Very few educators thus have the necessary skills and knowledge to present the subject with confidence, let alone teach the arts in an integrated way whilst, as Herbst et al (2005: 261) note:

[the] South African Department of Education expects general class educators, who have little or no specialized music training, not only to teach musical concepts to their classes but also to integrate the expressive arts into other non-music subjects such as Numeracy and Literacy.

According to the Report of the Task Team for the Review of the Implementation of the National Curriculum Statement (2009:10), one of the key discussions was about educators and training. This document states that:

...addressing the need to upgrade educators' skills would not be appropriate with a 'one size fits all' approach. Educators also complained that most tertiary institutions did not cover the 
curriculum thoroughly enough and that many newly trained educators were not competent to teach.

The same report (2009:59) acknowledges the need for training more educators in certain new subjects, including Arts and Culture. Since this report, the subject Arts and Culture has changed to Life Skills in the Foundation and Intermediate phases and Creative Arts in the Junior Secondary Phase. However, the challenge with music remains pertinent.

Ballantyne (2006:38) stresses that the quality of teaching in general and of music specifically in schools can be directly attributed to pre-service educator preparation. Martin and Ross in Ryan (1988:3) add another dimension and say that 'the training of arts educators has two major components which, though seldom designed to complement and support each other, are often confused: pre-service and in-service training'. The researcher believes that both aspects, pre-service and in-service training, are essential ingredients in assisting educators to achieve good results. Regular in-service training is required to 'soften the blow' of curriculum change as well as the effect of educators being moved from one subject to another.

Investigating South African universities' 2014 curricula reveals that the situation where new schoollevel subjects are not addressed is specifically noticeable in LS/CA with its different facets. Music specialization is generally offered in Intermediate Phase B.Ed degrees but this does not alleviate the challenge for non-specialist educators teaching music.

Table 1 sketches the current situation in Intermediate Phase B.Ed educator training for LS/CA at some of the major universities in South Africa as contained in the 2014 faculty yearbooks of the different institutions. 
Table 1. LS/CA training within Intermediate Phase B.Ed curricula in South African institutions

\begin{tabular}{|l|l|}
\hline University & Life Skills in Intermediate Phase B.Ed \\
\hline Cape Town & No B.Ed offered \\
\hline Fort Hare & Individual Arts subjects offered as electives - no Life Skills \\
\hline Free State & Offered as compulsory subject \\
\hline KwaZulu Natal & Creative Arts, Life Orientation and Life Skills are compulsory \\
\hline Limpopo & Life Orientation or Arts offered as electives \\
\hline North-West & Life Orientation and Creative Arts offered as electives \\
\hline Pretoria & Art or Music or Life Orientation offered as electives \\
\hline Rhodes & No B.Ed offered \\
\hline Stellenbosch & No compulsory Life Skills or Creative Arts or Life Orientation \\
\hline Witwatersrand & $\begin{array}{l}\text { Offered as compulsory subject but in the format of Life } \\
\text { Orientation and Creative Arts }\end{array}$ \\
\hline Johannesburg & $\begin{array}{l}\text { Culture and the Natural Environment (Life Skills content) } \\
\text { offered as elective }\end{array}$ \\
\hline Nelson Mandela Metropolitan & Arts and Life Orientation compulsory \\
\hline Venda & No B.Ed Intermediate Phase offered \\
\hline Walter Sisulu & No B.Ed Intermediate Phase offered \\
\hline Zululand & B.Ed phased out \\
\hline Rhodes & No B.Ed offered \\
\hline
\end{tabular}

\section{In-service educator challenges}

Support for music educators in South Africa needs improvement, just like in the United Kingdom (UK). Stocks (1998) in Holden and Button (2006:26) acknowledges that music specialists are scarce but says that non-specialist music educators can be helped to find confidence through in-service training, access to resources and in-class support by a music specialist. Support is seen as a tool in turning a negative situation around, where a non-specialist can become a confident music educator through appropriate support. Jansen van Vuuren (2010) confirms that support networks for arts educators are scarce - most provinces now have LS/CA Senior Education Specialists but only a small number of them have music training and the required knowledge to be able to support educators adequately. 
Gillian Stunell (2006:3) adds her voice to the growing predicament of both pre-service and in-service music educators: ' ... unless future political priorities enable greater support for educators, both in initial training and in-service development, children will continue to be deprived of this right.' The lack of music knowledge amongst LS/CA educators has resulted in many keen learners not being able to take Music as a subject in the Further Education and Training (FET) phase due to not having an adequate background to the subject. The situation described above seems to apply to Australia as to South Africa. At a Music Council of Australia workshop, Broad (2007:1) claims the following statements were agreed on by participants as final recommendations:

Ensure that all educators and individuals involved in the provision of music education in Australian schools have the skills to deliver programs that reflect the world's best practice. Afford music the status of a core area of learning within all Australian schools and all Australian school systems. Reaffirm the many benefits, including academic, social, economic and artistic - of active music making for all schoolchildren in Australia.

The above report emphasizes the necessity of having well-trained educators when it says, 'the bottom line seems to indicate that a good, well-trained teacher can deliver excellent outcomes using a modest curriculum, whereas even the best curriculum cannot make a modest teacher great' (Broad 2007:1).

Perhaps surprisingly, the music situation in schools in the UK seems to have similar challenges to those experienced in South Africa. In a report by Harland et al (2000:9), entitled Arts Education in Secondary Schools: Effects and Effectiveness, we are reminded that individual teacher factors are more important determinants of effectiveness than whole-school factors.' The importance of educator training is thus emphasized. To substantiate this report the research by Holden et al (2006) showed a significant link between teacher training and teachers' levels of confidence in teaching music in the primary school.

The Stevens Report (2003), as mentioned in 'Improving the condition of school music education across Australia' (ACSSO Submission to National Review of School Music Education 2005:3), deals mainly with music educators' in-service challenges. It mentions that a particular problem identified in Australian schools is 'the unrealistic expectation, particularly of government primary schools, that 
classroom music will be taught by generalist primary school teachers.' Unfortunately, this 'unrealistic expectation' is also evident in LS/CA in South Africa.

As Arts and Culture educator at a prestigious Afrikaans school from 2004 to 2008, with learners of mostly middle and higher socio-economic status coming from a variety (36) of feeder schools, the first researcher found no learners in the Arts and Culture class with any knowledge about metre and notation, for example, except the ones who studied music privately. If this lack of proper teaching is encountered in more affluent primary schools where educators with a more formal music education are easier to find than elsewhere, the obvious question arises as to what is the hope that the situation is better in previously disadvantaged schools where very few educators have had the privilege to take private music lessons. Dr Petrus Krige (2014), Deputy Chief Education Specialist in Creative Arts at the Free State Department of Education, says that less than 1\% of Creative Arts educators can read any form of music notation. Seventy percent of the $1 \%$ can only read solfa notation. The rest do have an idea of stave notation. A very small minority has had music training. He also adds that principals give the arts to a teacher with an open slot on the timetable and that is the reason why so many music illiterate educators are teaching the subject.

Table 2 below gives a summary of common challenges experienced in the arts in the different provinces of South Africa.

Table 2. Challenges in Life Skills and Creative Arts in South Africa

\begin{tabular}{|l|l|l|}
\hline Challenge & Province & Reference $^{1}$ \\
\hline Educators were not trained for the learning & Western Cape & Lewis (2010) \\
area and do not have the knowledge to & Free State & Rademan (2010) \\
teach music effectively. Specialist & KwaZulu Natal & Nkumane (2014) \\
educators are often only trained in one or & Gauteng & Smith (2010) \\
two of the required art forms and the rest of & KwaZulu Natal & Jansen van Vuuren (2010) \\
the learning area is neglected. & KwaZulu Natal & Mkhize (2009) \\
\hline Educators are frequently moved from one & & \\
\hline
\end{tabular}

\footnotetext{
${ }^{1}$ All individuals mentioned here were/are subject advisors for Arts and Culture/ Life Skills in the different provinces.
} 


\begin{tabular}{|c|c|c|}
\hline $\begin{array}{l}\text { learning area to another and do not get } \\
\text { enough time to obtain even a modicum of knowledge in } \\
\text { learning area. }\end{array}$ & $\begin{array}{l}\text { Gauteng } \\
\text { KwaZulu Natal } \\
\text { North West }\end{array}$ & $\begin{array}{l}\text { Smith (2010) } \\
\text { Jansen van Vuuren (2010) } \\
\text { Crouse (2010) }\end{array}$ \\
\hline $\begin{array}{l}\text { Very few subject advisors are specialists in } \\
\text { music; they can therefore not assist and } \\
\text { support educators regarding content. Some } \\
\text { subject advisors were moved from former } \\
\text { colleges of education and are often working } \\
\text { in learning areas outside their specialization. }\end{array}$ & $\begin{array}{l}\text { Free State } \\
\text { Free State } \\
\text { KwaZulu Natal } \\
\text { Limpopo } \\
\text { North West }\end{array}$ & $\begin{array}{l}\text { Krige (2014) } \\
\text { Rademan (2010) } \\
\text { Nkumane (2014) } \\
\text { Mashamaite (2014) } \\
\text { Crouse (2010) }\end{array}$ \\
\hline $\begin{array}{l}\text { Resources are a major challenge. There are } \\
\text { very limited resources at schools and } \\
\text { training programs presented by the } \\
\text { Department of Basic Education (DBE) are } \\
\text { often interrupted by a lack of financial } \\
\text { resources. }\end{array}$ & $\begin{array}{l}\text { KwaZulu Natal } \\
\text { Western Cape } \\
\text { KwaZulu Natal } \\
\text { KwaZulu Natal }\end{array}$ & $\begin{array}{l}\text { Jansen van Vuuren (2010) } \\
\text { Lewis (2010) } \\
\text { Nkumane (2014) } \\
\text { Mkhize (2009) }\end{array}$ \\
\hline $\begin{array}{l}\text { Many principals and educators regard } \\
\text { Creative Arts as non-essential and the } \\
\text { subject is given to educators as a "filler" } \\
\text { subject. }\end{array}$ & $\begin{array}{l}\text { Free State } \\
\text { Western Cape } \\
\text { KwaZulu Natal } \\
\text { Limpopo }\end{array}$ & $\begin{array}{l}\text { Krige (2014) } \\
\text { Lewis (2010) } \\
\text { Jansen van Vuuren (2010) } \\
\text { Mashamaite (2010) }\end{array}$ \\
\hline
\end{tabular}

\section{Methodology}

The pragmatic paradigm used for this study is described by Mackenzie and Knipe (2006) as having the following characteristics: aspects of mixed models, consequences of actions, problem-centeredness, and being pluralistic and real-world practice orientated. The general characteristics of pragmatism as described by Burke Johnson and Onwuegbuzie (2004:18) that are well-suited to this research are:

...that pragmatism recognizes the existence and importance of the natural or physical world as well as the emergent social and psychological world that includes language, culture, human institutions and subjective thoughts. Pragmatism places high regard for the reality of and influence of the inner world of human experience in action. In pragmatism knowledge is viewed as being both constructed and based on the reality of the world we experience and live in. 
A variety of sampling types were used; thirty educators teaching LS/CA were randomly selected from schools in different circuits and wards in the Vryheid District to gain information regarding curriculum knowledge, training, resources, challenges, qualifications and support systems in their subject. They signed consent forms and were asked to fill out a questionnaire face-to-face so that certain English terminology could be explained that could have been unclear. This was necessary due to the majority of educators in the Vryheid Education District being Zulu speakers and having English as their second or third language and oftenhaving difficulty conversing in English despite the fact that they are required to be teaching in English.

Senior Education Specialists from different provinces were contacted to gain information regarding educator challenges and possible solutions. All of those interviewed worked/are working in LS/CA. Most of the respondents living outside the Vryheid District were requested to sign a letter of consent and answer a questionnaire that was e-mailed to them or done telephonically or during a cluster ${ }^{2}$ meeting. The rest of the Senior Education Specialists were interviewed face-to-face in Vryheid.

Academics and authors of music books and music programs who are directly or indirectly involved in music tuition at schools were also consulted to gain information regarding educator training, challenges and possible solutions. These respondents were requested to answer a questionnaire that was e-mailed to them. In addition, ongoing internet correspondence took place to obtain information about related music matters in their respective provinces.

Further conclusions were reached through textual analysis; content analysis of the music strand of the CAPS Life Skills curriculum, content analysis of the music strand of the Curriculum and Assessment (CAPS) policy and literature analysis for information about the situation in music in primary schools in other countries.

\footnotetext{
${ }^{2}$ Cluster meetings comprise all the Life Skills and Creative Arts subject advisors from KZN meeting to discuss subject matters.
} 


\section{Results and findings}

The following results were obtained from the various data collection methods in the different research aspects:

\section{Pre-service educator training and qualifications}

A list was given to educators where highest qualifications had to be indicated to determine their general academic qualification levels. The results are summarized in table 3.

Table 3. Academic qualifications of LS/CA educators (30 respondents)

\begin{tabular}{|l|l|l|}
\hline Academic qualifications & Number of educators & $\%$ \\
\hline Professional teaching qualifications & 13 & 43.33 \\
\hline Post-professional teaching qualifications & 5 & 16.66 \\
\hline First academic qualifications & 1 & 03.33 \\
\hline Post graduate qualifications & 4 & 03.33 \\
\hline None & 2 & 13.33 \\
\hline Other (electrical engineering diploma, public management dipl & 2 & 06.66 \\
\hline Still studying & 4 & 13.33 \\
\hline
\end{tabular}

A third of the LS/CA respondents are not qualified teachers or are still studying to obtain teaching qualifications and besides having to cope with the content of a specialist area like music, they thus have the additional burden of having to cope with a study schedule.

Table 4 gives a summary of the outcomes of a questionnaire to determine the instrumental skills of current LS/CA educators. 
Table 4. Competencies in instrument playing

\begin{tabular}{|c|c|c|c|c|}
\hline 2 & Instruments played & Level of competency & Number of educators & Percentage \\
\hline a) & Melodica & Good & 2 & 06.66 \\
\hline b) & Recorder & Good & 2 & 06.66 \\
\hline c) & Voice & Post-graduate & 1 & 03.33 \\
\hline d) & Piano & Basic & 1 & 03.33 \\
\hline d) & Piano & Grade 3 & 1 & 03.33 \\
\hline e) & Drums & Basic & 2 & 06.66 \\
\hline f) & Shakers & Basic & 1 & 03.33 \\
\hline g) & Electronic keyboard & Grade 3 & 2 & 06.66 \\
\hline h) & Guitar & Good & 3 & 10.00 \\
\hline i) & None & N/A & 22 & 73.33 \\
\hline
\end{tabular}

Most of the respondents, 73,33\%, cannot play any music instrument and will find it extremely difficult to teach learners how to play an instrument as is required in the CAPS curriculum where both percussive and melodic instruments need to be played.

Figure 1 below gives a visual representation and summary of formal music qualifications amongst LS/CA educators in the sample group.

Figure 1. Music qualifications

\section{Music Qualifications of LS/AC educators}

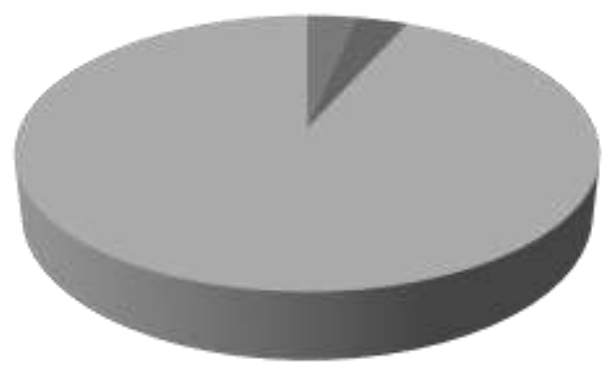

B.A Music Honours

- Short course at college

No music qualification 
93.3\% of these educators do not have any music qualifications; it is therefore not possible for them to do justice to music in LS/CA.

\section{In-service educator challenges}

Subject advisors should be the first port of assistance for educators. The advisors, of whom the first researcher was one, were given a basic one day training course in each of the art forms before the CAPS curriculum was rolled out. Due to many advisors not working in their fields of competence, this did not suffice. None of the music presenters at these courses were specialists and some of the training was inaccurate and confused non music specialist advisors even more.

After the first researcher left the Zululand District, two advisors remained for Life Skills and two for Creative Arts of whom none has any arts qualification, yet these advisors are responsible for offering workshops in all curriculum aspects.

Clusters, where smaller groups of educators are grouped together to form a peer support system have not been successful in most parts of this district due to great distances between schools and educators often being moved into other subject areas as soon as they have gained a modicum of knowledge.

To determine what the content knowledge challenges are amongst educators, they were given a questionnaire where the content of the curriculum was penned. Studying the results, it is understandable why music cannot thrive in LS/CA and why it is not progressing as a subject. Figure 2 below gives a visual representation of aspects as found in the curriculum wherein educators from NKZN need to be trained, as opposed to those in which they feel confident: 
Figure 2. Aspects where training is needed

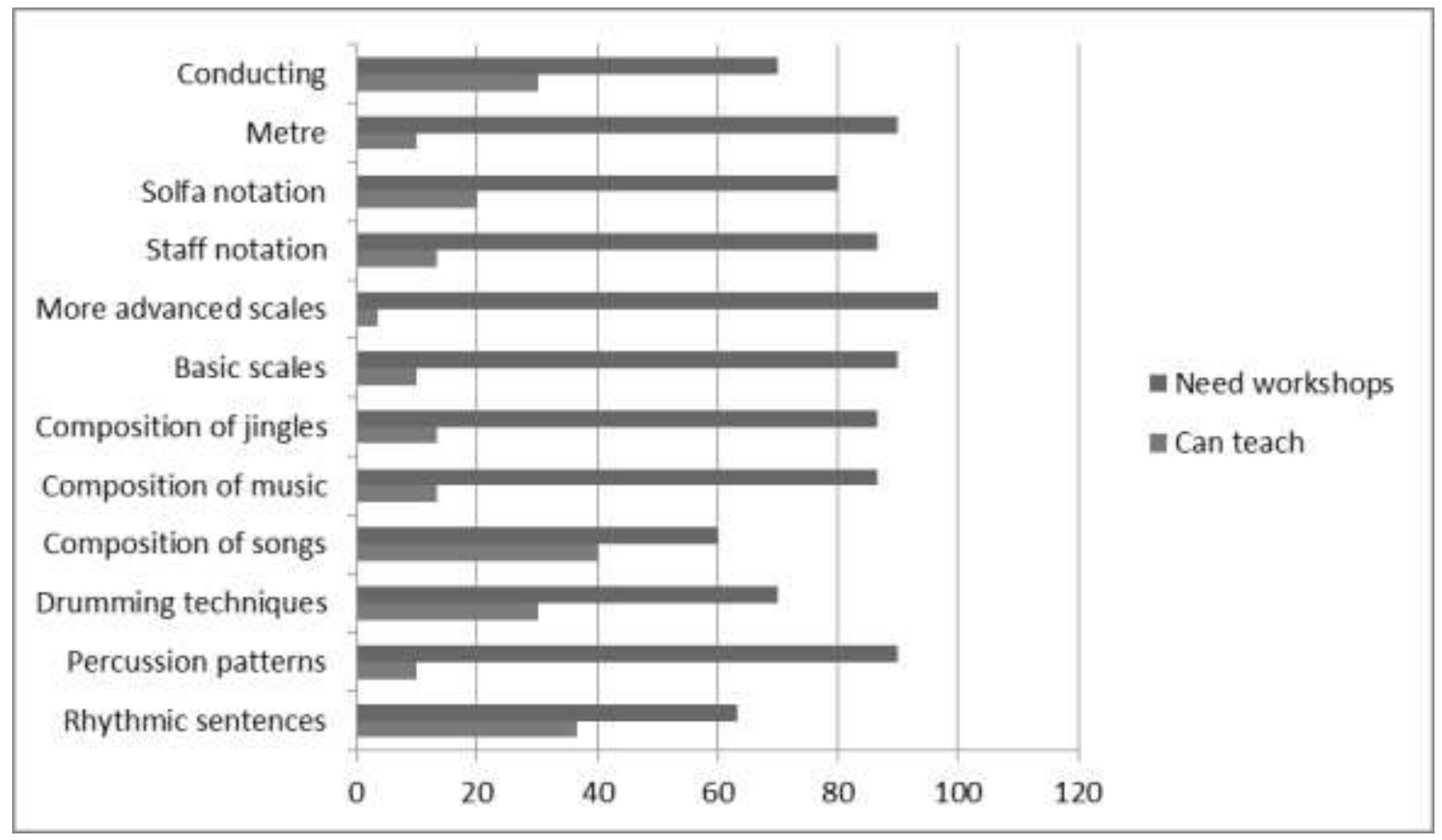

The only aspects of the curriculum that between $30 \%$ and $40 \%$ of LS/CA educators claim they can teach to a certain extent are rhythmic sentences, composition of songs and conducting. Composition in this case does not mean composing with actual notation - it only means creating a song and performing it from memory. The rest of the educators need training in every aspect of the curriculum. In effect this means that in the best scenario, less than a quarter of the music curriculum can be taught by the educators of NKZN. These findings correspond with the first researcher's experience when conducting workshops.

Training for LS/CA educators is essential but there are also logistical factors impacting negatively on training. The Department of Basic Education does not allow workshops to be conducted before $12 \mathrm{~h} 00$ which causes some educators not to be able to get transport home after workshops. ${ }^{3}$ Financial restrictions make workshops that last longer than a day very difficult as educators mostly have to pay for their own transport, accommodation and meals.

\footnotetext{
${ }^{3}$ Some parts of the Pongola area have a bus at $7 \mathrm{~h} 00$ and then another bus at $13 \mathrm{~h} 00$. After these times you have to rely on luck and passers-by for transport.
} 


\section{Resources}

The graph below was compiled using information from a questionnaire regarding available resources given to the $30 \mathrm{LS} / \mathrm{CA}$ educators. All CDs/DVDs needed for teaching were grouped together.

Figure 3. Availability of resources

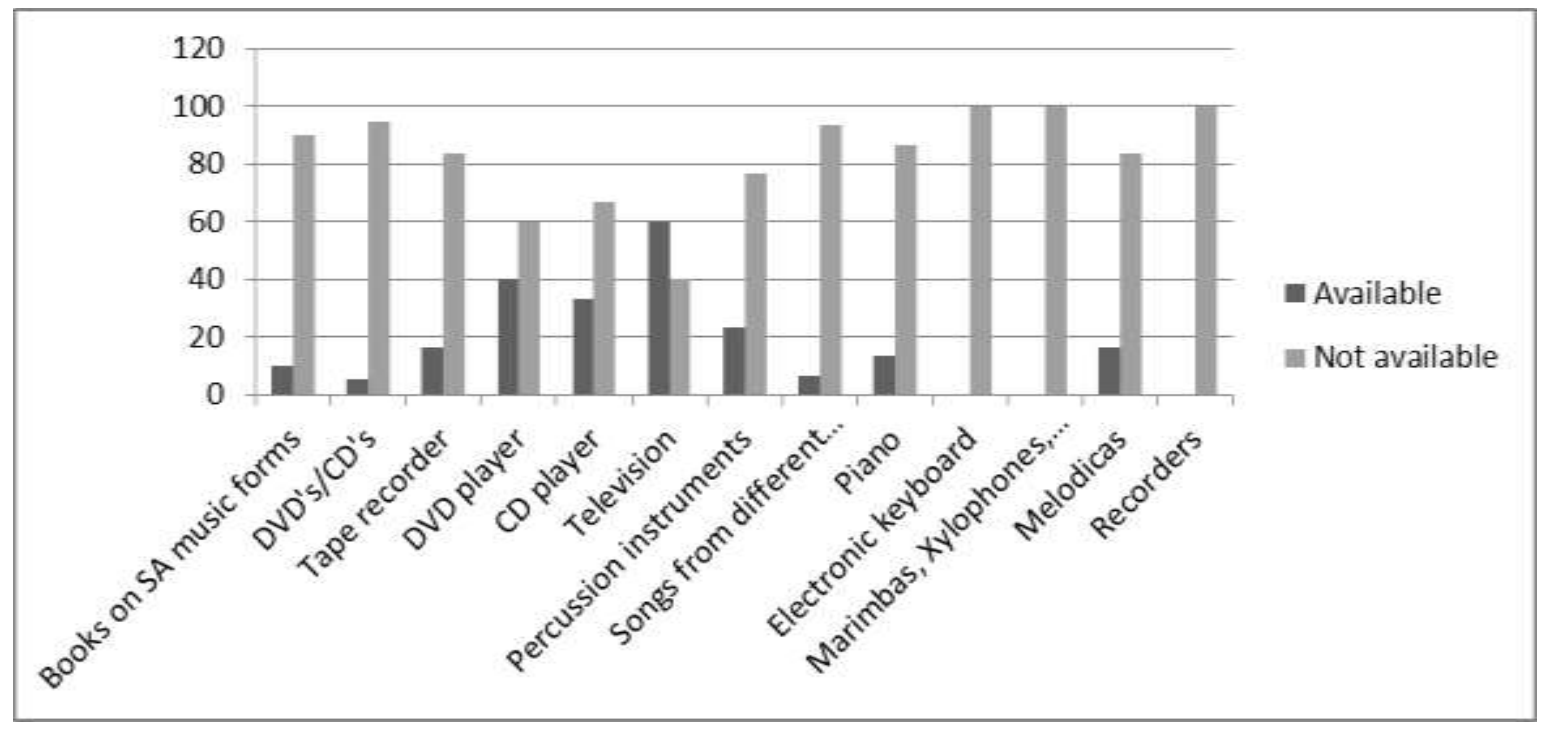

As can be seen on the graph, resources are not available in schools to teach music effectively. There is a perception amongst educators of previously disadvantaged communities that former model $\mathrm{C}$ schools ${ }^{4}$ are in possession of all the necessary resources to facilitate LS/CA, yet the reality is different. Even previous model C schools in the Vryheid District lack resources like suitable DVDs, CDs and music instruments to teach music in Creative Arts. Such schools do, however, have pianos and often have trained music educators which should give them an advantage in teaching music. Nevertheless, due to principals not always realizing the value of the subject, these educators are used in other subjects and the pianos become unutilized embellishments.

Rademan (2010) says that the educators in her district in the Free State do not have the ability to develop resource materials for themselves and they cannot use a library. Yet contrary to what is often heard in the media, she notes that most schools do have some kind of a library where she often finds

\footnotetext{
${ }^{4}$ Affluent public schools, usually urban, that were largely for whites during the apartheid era.
} 
'marvelous books on the arts - always brand new and unused'. They don't have the ability to find material in a library book which links up to the content that they should cover.'

The majority of African educators are of the opinion that the government should supply the resources needed to teach. Although $60 \%$ of schools have television sets, they can often not be used due to lack of electricity. In old model C schools, most educators buy their own materials to make resources such as posters.

During the investigative process of what was actually happening in schools, some dedicated educators were found who were truly devoted to the arts and doing positive teaching despite all the challenges. Some educators at the other end of the spectrum have done almost nothing because they 'don't know what to do.' The researchers' expectations were to find ex-model C schools doing what is expected of them and former African schools submerged in chaos as the media tends to suggest. In reality many African schools are doing some remarkable work despite the challenges with resources. In some exmodel $\mathrm{C}$ schools it was found that a large quantity of work was being done and that projects and tasks were of a high standard. Unfortunately some of these ex-model C schools were not following the curriculum and educators even admitted to 'not knowing what is going on' in the curriculum. One exmodel $\mathrm{C}$ school was blatantly avoiding the curriculum and had a singing lesson weekly instead of Life Skills whilst the remaining periods were allocated to 'more important subjects.'

In the traditionally African schools there were two main styles of teaching music within LS/CA. The one group let the learners dance or sing (something most African children can do well) and the other group were only taught "about" music (Elliott 1995:12) without the learners being exposed to active music making. Music instruments that were made by learners were lying around unused in most schools and were not utilized as resources for music making - they were mere art objects.

\section{Discussion and possible solutions}

When studying the literature and interviewing stakeholders in music education a wide range of solutions were suggested to alleviate challenges in music education in South African schools. The solutions have been roughly divided into 2 main categories; pre-service solutions and in-service 
solutions. The pre-service section focuses on undergraduate training and the in-service section comprises subject advisors, workshops, resources and mentoring.

\section{Pre-service solutions}

According to yearbooks, there are only four universities that are presently offering full LS/CA courses in the B.Ed Intermediate program where any student can follow the courses without having a certain music background: the universities of the Free State, KwaZulu Natal, Witwatersrand and Nelson Mandela Metropolitan. Some South African universities are offering LS/CA to students with a background in the arts and some allow students to choose one or two of the art forms as an elective. The situation needs to be addressed where a subject that forms a compulsory part of the curriculum is not offered to the general B.Ed Intermediate Phase student who will in most cases end up having to teach it. The researchers find it difficult to understand that a country has a curriculum in place but that the corresponding training is not being monitored at national level.

Annemarie Alkema (2010), author of school music textbooks, points out that universities are often negative and criticize the school curriculum without seeing the positive elements. Universities then do not train educators in a way that will enable them to teach confidently upon graduation. Many university lecturers do not have in-depth knowledge about what is happening in schools. This disjuncture between university training and what is happening in schools needs to be addressed. Lecturers should be directly involved in schools through their community work so that they can keep in touch with the realities of the schooling system. Curriculum developers and module planners should ensure that university curricula are aligned with school curricula.

Where universities are offering LS/CA, more time should be allocated to the subject. The researchers see the arts as a supporting vessel for the rest of the school curriculum. This vessel needs to be made leak proof by ensuring appropriate and solid arts skills for students. Schalk Fredericks (2010), Teaching Advisor at the Academic Support Services of the Potchefstroom Campus of the North West University (NWU), proposes that more time should be allocated to the arts and that it should be offered over the entire four year program at universities. The case where universities have only one semester 
module to teach students all four art forms should be revisited. A solid foundation cannot be acquired in such a limited time period.

\section{In-service solutions}

Due to the subjects LS/CA being fairly new it is essential that generalist educators are upgraded and trained to be able to teach the art subjects which include music.

The low esteem of the subject is impacting directly on learners who are being robbed of knowledge of and experience in the arts. Instability caused amongst educators because of being moved between subjects needs to be addressed. Erna Rademan (2010), Senior Education Specialist in the Free State, suggests that principals be required to keep educators in the same subject for at least five years so that training done by subject advisors is not 'wasted' when educators are moved to another subject.

Universities should be at the forefront of in-service training. The NWU-Potchefstroom has been offering supplementary courses (Van der Merwe, 2010) for educators with inadequate knowledge and skills to teach music effectively. These courses are being offered during school holidays. If these supplementary courses could be introduced at more universities, the level of music education will improve, alleviating the challenge of upgrading subject advisors and educators alike in practical music that cannot be taught through correspondence.

Britz (2010) and Faber (2010) underlines that subject advisors, who have to do the training of generalist educators need to be suitably qualified to assist in remedying the situation of insufficient content knowledge amongst educators. The researcher met and collaborated with all the subject advisors for Life Skills and Creative Arts in KZN on a regular basis; whilst some have excellent skills in music and some of the other art forms, some have virtually no skills in any of the art forms.

The researchers suggest that education specialists should be appointed in the following way: four specialists in each education district; one for music, one for drama and personal and social well-being, one for dance and physical education, one for visual arts. These specialists can then work across school 
phases and the distribution will help to ensure that each component of LS/CA receives the required attention to succeed.

All respondents agreed that training was necessary but had different views regarding the actual time of training and the group size. Alkema (2010) emphasises the importance of training and is supported by Rademan (2010) who suggests that eight to twelve week workshops should be funded by the Department of Basic Education (DBE) to systematically train educators in music during school hours. Krige (2010) is of a different opinion and believes that the basic aspects of both sol-fa and staff notation should be taught to the masses (approximately 50000 educators in the country) over a period of a year of intensive workshops. Smith (2010) has found that training educators in small groups (three to four) has paid dividends; individual attention ensures that educators grasp the taught music concepts and difficulties can be addressed immediately. Most of the respondents concur with Hoek (2010) that the only way to solve the curriculum knowledge problem is to have more workshops presented by experts in their field. The question remains whether educators will be able to attend so many workshops in one aspect of the subject. When will time be found for the training of the other three art forms; dance, drama and visual art and the remaining topics?

The first researcher found in practice that it helps to give educators fully prepared lesson plans and materials to ensure enough time to focus on acquiring content skills. Faber (2010) and Rademan (2010) have had the same experience. When the first researcher supplied educators of LS/CA in the Vryheid district with fully prepared lesson plans, notes, tests and rubrics during mentoring workshops, the enthusiasm for the subjects rose. Lessons were presented to educators in a condensed manner and when leaving, they knew exactly what to teach and how to teach it. Where educators have attended workshops, they were successful in using learning material; however, educators who did not attend workshops did not attempt to use the lesson material they received from their colleagues as could be seen during school visits. It is clear that given materials need to be workshopped to maximize implementation by educators.

Both Fredericks (2010) and Van der Merwe (2010) propose that technology should be better utilized to assist educators with music. Audio and visual support material should be made available through the 
Thutong ${ }^{5}$ educational portal to assist educators. Fredericks suggests the use of radio or TV broadcasts with a dedicated schedule coinciding with school timetables and programs. This avenue certainly requires exploration and can be a valuable tool. Educators, of whom many are not technologically skilled, need assistance in obtaining skills to be able to use the internet. Educators in rural areas have the obstacle of not always being in an area where there are internet cafes and good cellphone reception. This will hopefully be improved in the near future but the cost of computers and internet connection is high and educators cannot always afford these luxuries. Many schools do not have electricity and therefore no computers.

Alkema (2010) reminds us that there are numerous self-help books of a good standard available to assist in-service educators who are experiencing difficulties in teaching LS/CA. All principals should ensure that arts educators also receive at least R1000 annually per art form to buy the necessary resources. This will enable educators to gradually add resources for the music class. The researchers agree with Alkema, but stress that even the best resources will not be of any use unless the teachers know how to use them. The researchers are of the opinion that the DBE should supply a kit to schools containing the following: A battery operated CD player and CDs with sound examples of instruments, songs and music styles and a set of 35 to 40 melodicas/recorders so that a whole class can receive tuition simultaneously.

Further resources like percussion instruments can be made in class; it is necessary to motivate and inspire educators to think creatively and find innovative ideas to present music with the limited resources at hand.

Mentoring has become a buzzword in business and education alike and is discussed in a wide variety of literature. One of the reasons why a good mentoring program can make a considerable difference in education and specifically in LS/CA is described by White and Mason (2003) as capitalizing on an existing resource (senior music education specialists and music qualified educators teaching the music

\footnotetext{
${ }^{5}$ Delivering information, curriculum, and support materials to the South African schooling and FET college community.
} 
strand of LS/CA). Substantial evidence exist that mentoring increases retention and teacher satisfaction and also strengthens school programs (Richardson et al, 2007).

The researchers see mentoring as an all-encompassing ultimate solution. In South Africa's current situation where many educators are not suitably trained, especially for the newer subjects like LS/CA, mentoring can play a significant role. The vastness of the training challenge can be understood when one considers that all primary and junior secondary schools have to offer Life Skills (Foundation and Intermediate Phases) or Creative Arts (Senior Phase) and that there is an average of two to three educators per school involved in arts teaching. A mentoring program uses human resources that are easier to find in the schooling system than monetary resources needed for training programs by external parties and is a feasible way to reach educators.

The main purpose of a mentoring program would be to develop content knowledge and didactic skills for music amongst subject advisors and generalist educators alike. Universities would need to be leaders in starting mentoring programs firstly for subject advisors and then for educators. School visits where mentors and mentees can meet in the work situation to find solutions to challenges are essential to narrow the divide between academic training and school realities. Mentees should have easy access to mentors through technology, to ensure that distance does not become an obstacle.

A mentoring model that is multi-directional and multi-levelled will be more effective than the traditional single mentor-mentee model in rural South Africa. The first researcher offered such a multidirectional, multi-levelled formal mentoring program in NKZN for educators and a marked improvement in knowledge and attitude was seen amongst teachers in music tuition when school visits were made. Common tests done by all learners in the district confirmed the positive results of the program. The program included different mentoring styles and types. Fellow subject advisors were mentored to be able to cope with basic music skills and were assisted during workshops to train educators in music. Some confident educators with music knowledge further assisted the subject advisors by mentoring peers from neighbouring schools. Mentoring models used included peer mentoring, face-to-face mentoring, virtual mentoring, informal mentoring, formal mentoring and role reversal mentoring where mentees became mentors in certain aspects. 
Figure 4 shows levels that should be included in a successful mentoring program for music educators.

Figure 4. Multi-directional and multi-levelled mentoring program

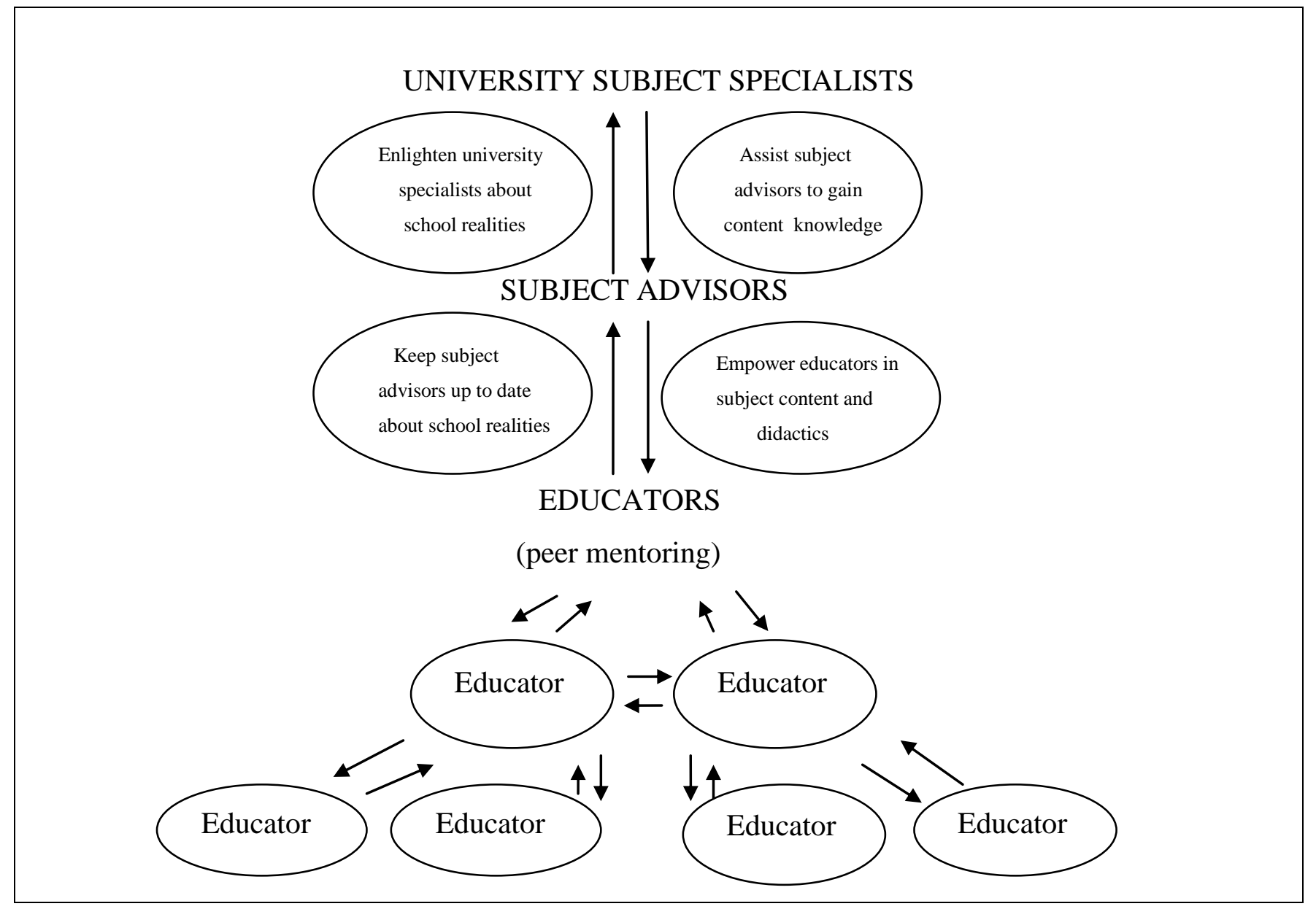

\section{Conclusion}

The most pressing dilemma which causes music in South African schools to be marginalized is the lack of appropriate music knowledge amongst generalist educators. If the root cause, lack of training, is not addressed and made compulsory for generalist education students, the problem will not be resolved. Universities need to revise and align their curricula to at least cover school syllabi to ensure that newly trained educators go into the teaching field with confidence and the ability to impart their music knowledge and in turn also to mentor in-service educators. This would be a situation of alternating the mentor-mentee roles where experienced educators could assist with general teaching skills whilst their own skills are expanded by their mentees. Intensive in-service training should be 
implemented to firstly empower subject advisors who are not competent in their advisory areas to have the necessary content knowledge to become mentors. Thereafter monitored mentoring programs should reach educators. Virtual music applications with interactive training modules should be explored, developed and utilized by universities to train pre-service educators and to take music skills to generalist in-service educators. Educators should be equipped to think creatively and develop their own

simple resources to add to the music experience. Only then, will music tuition have a chance of surviving successfully in rural schools.

\section{References}

ALKEMA, A. (2010) E-mail to E. Jansen van Vuuren, 2 July 2010.

BALLANTYNE, J. (2006) Reconceptualising Preservice Teacher Education Courses for Music

Teachers: The Importance of Pedagogical Content Knowledge and Skills and Professional Knowledge and Skills. Research Studies in Music Education 26: 37-50.

BRITZ, E. (2010) E-mail to E. Jansen van Vuuren, 12 June 2010.

BROAD, T. (2007) Music Council of Australia - National Review of School Music Education: Report from the national workshop. Retrieved from: http://www.mca.org.au/web/content/view/78/6 (accessed 9 April 2013).

CROUSE, T. (2010) Telephonic interview with E. Jansen van Vuuren, 18 October 2010.

ELLIOTT, D.J. (1995) Music matters. A new philosophy of Music Education. New York: Oxford University Press.

FABER, H. (2010) E-mail to E. Jansen van Vuuren , 3 April 2010.

FREDERICKS, S. (2010) E-mail to E. Jansen van Vuuren, 11 April 2010.

HERBST, A., DE WET, J. \& RIJSDIJK, S. (2005) A Survey of Music Education in the Primary Schools of South Africa's Cape Peninsula. Journal of Research in Music Education, 53(3): 260-283.

HOEK. A. (2010) E-mail to E. Jansen van Vuuren, 18 April 2010.

HOLDEN, H. \& BUTTON, S. (2006) The teaching of music in the primary school by non-music specialists. British Journal of Music Education. 23(1): 23-38. 
JANSEN VAN VUUREN, E.N. (2010) Subject music in rural South Africa: challenges and solutions within a comparative context. Unpublished doctoral dissertation. Pretoria: University of Pretoria.

JOHNSON, R. \& ONWUEGBUZIE, A. (2004) Mixed Methods Research: A Research Paradigm Whose Time Has Come. Retrieved from: http://www.aera.net/uploadedFiles/Journals_and_Publications/Journals/Educational_Resea rcher/Volume_33_No_7/03ERv33n7 Johnson.pdf (accessed 2 August 2013).

KRIGE, P. (2014) E-mail to E. Jansen van Vuuren, 14 May 2014.

LEWIS, F. (2010) E-mail to E. Jansen van Vuuren, 19 April 2010.

MACKENZIE, N. \& KNIPE, S. (2006) Research dilemmas: Paradigms, methods and methodology. Issues in Educational Research, 16(2):193-205. Retrieved from: http://www.iier.org.au/iier16/mackenzie.html (accessed 5August 2012).

MASHAMAITE, D. (2010) E-mail to E. Jansen van Vuuren, 8 May 2010.

MKHIZE, S. (2010) E-mail to E. Jansen van Vuuren, 5 April 2010.

MOUTON, J. (2003) How to succeed in your Master's and Doctoral studies. Pretoria: Van Schaik.

NKUMANE, M. (2010) Personal interview in Vryheid TLS office with E. Jansen van Vuuren. 13 August 2010.

RADEMAN, E. (2010) E-mail to E. Jansen van Vuuren, 20 September 2010.

REPORT OF THE TASK TEAM FOR THE REVIEW OF THE IMPLEMENTATION OF THE NATIONAL CURRICULUM STATEMENT. (2009) Retrieved from: http://www.naptosa.org.za/downloads/Review_NCS.pdf. (accessed 10 December 2012).

RICHARDSON, R. C., GLESSNER, L. L., \& TOLSON, H. (2007) Stopping the Leak: Retaining Beginning Teachers. Australian Journal of Teacher Education, 32(2).Retrieved from: http://dx.doi.org/10.14221/ajte.2007v32n2. (accessed 2 February 2014).

RYAN, B. (Ed). (1988) Toward a new era in Arts Education. New York: Bookcrafters. SMITH, A. (2010) Telephonic interview with E. Jansen van Vuuren, 27 October 2010. SOUTH AFRICA. DEPARTMENT OF BASIC EDUCATION. (2011) Curriculum and Assessment Policy Statement. (CAPS) Life Skills - Foundation Phase. Retrieved from http://www.education.gov.za (accessed 10 July 2013). 
SOUTH AFRICA. (1994) RDP office. White paper on the reconstruction and Development Programme. Cape Town. Government Printers.

SOUTH AFRICA. (2013) Unemployment statistics South Africa. Retrieved from: http://www.statssa.gov.za/news_archive/Docs/QLFS_Press_statement_Q1_2013.pdf (accessed 13 December 2013).

STEVENSON, L.M. \& DEASY, R.J. (2005)Third Space - when learning matters. Washington: Arts Education Partnership.

THE AUSTRALIAN COUNCIL OF STATE SCHOOL ORGANIZATIONS (ACSSO). (2005) Improving the condition of school music education across Australia. Retrieved from: www.acsso.org.au/sub_nrsme.doc (accessed 12 February 2013).

VAN DER MERWE, L. (2009) Evaluating conceptual progression of music assessment standards in the Learning Area Creative Arts (Grades R-9) Musicus 37(2):13 - 30. UNISA Press.

VAN DER MERWE, L. (2010) E-mail to E. Jansen van Vuuren, 14 June 2010.

VAN NIEKERK, C. AND JANSEN VAN VUUREN, E. N. (2012) "Mentoring the Muse" Paper presented at the annual meeting of the ISME World Conference and Commission Seminars, Thessaloniki Concert Hall, Thessaloniki, Greece. Retrieved from http://citation.allacademic.com/meta/p548777_index.html (accessed 7 December 2013).

WHITE, M., \& MASON, C. (2003) Mentoring Induction Principles and Guidelines. Retrieved from: http://www.cec.sped.org/content/NavigationMenu/ProfessionalDevelopment/ProfessionalStandards/mi p_g_manual_11pt.pdf (accessed 10 January 2014).

Word count: 7209 